\title{
鉄鋼生産管理への直読式分光分析装置適用上の諸検討*
}

\author{
阿部吉彦** . 山田雄康*** . 原田保馬***
}

\section{Some Studies on the Use of Direct Reading Spectrometer for Control of Steelmaking Process.}

\author{
Yoshihiko ABe, Yūkō YAmAda and Yasuma Harada
}

Synopsis:

The Production of steel is of course desirable a quick and an accurate analysis of various kind of steels and slags, and we tried to realize this demand with the developement of Direct Reader (Baird Atomic Inc., U.S.A.). But when a direct reading spectrometer has to be applicated for all of these samples there were much troubles to study, and in this report we had the investigations for these troubles.

It was necessary for spectrochemical analysis of iron or steel that the source unit is given the share of spark or arc with the kind of and the concentration of analytical element. But as the matrix effects of samples were possible to be neglected by the adjustment of discharge condition, we could use same technique on the analysis of all kind of samples with the production of low alloy steel, and get the analytical results avilable within normal error of chemical method.

Rapid analysis of slag was possible with a briquetting technique; analysed with spark discharge the sample which pressed the mixture with carbon powder. Working curves of the element in slag were showed with a single curve except those of $\mathrm{Fe}$, forming the different curve caused to the kind of iron-oxide on the period of sampling.

Now we tried to use this spectrometer for the production of steel $24 \mathrm{~h}$ a day, 7 days a week. Therefore the strict checks on operating and instrument were essential, but it became clear that these controls were easy with the application of standard sample at regular interval and with the check of internal standard intensity coincided with analysis.

(Received 12 October 1962)

\section{I. 緒言}

製鋼操業を科学的に管理するために澡業過程での溶 鋼組成をできるだけ詳しくかつ汛速に知ると共に必要に 応じて溶㳯の組成をも適確に把握できるのが望ましい， そこで当所では 1961 年夏以来 U.S.A.の Baird Atomic Inc. のダイレクトリーダー (Direct Reader) を 設置して塩基性電気炉操業の炉前分析を含めた鉄鋼生産 管理に適用してきた. すなわちその実用状況は“ダイレ クトリーダーの炉前分析への適用”および“スラグの迅 速分光分析法”之言う標題でそれぞれ発表してあるが， この種の直読式分光分析装置で各種の鉄鋼試料掞よびス ラグのごとき酸化物質が一様に分析できるようになるま でには試料のマトリックス効果などに対処するる発光条 件の選定ならびに各種の試料を 1 台の装置で処理する場 合の作業方式の管理などの面て数多くの問題を検討しな ければならなかつた。もちろえこれらの問題の処理方法 は装置の種類および対象とする試料の種類などによつて 若干の相違があつても大部分は直読式分光分析装置に共
通した事柄と見ることができる.

ここで筆著等が対象にしたのは低合金鋼までであるが ダイレクトリーダーの特徵を生かすと試料ごとの複雑な 補正や管理方式を行うことなく上記の諸問題を処理でき る方式をえたので，本報ではこれらの方式をえるに到つ た検討経過について記す。

\section{II. 装置および分析元素}

(1) 装 置

設置した分光分析装置はダイレクトリーダーであつて つぎのごとき特性をもつている。

(1) スパーク発光用として空気ジット式,アーク発 光用として高圧交流式を使用する.

(2) 回折格子と射出スリットとの相対位置関係のズレ を自動的に調整できる Automatic Servo Monitor と 称する特殊器機が付属している.

* 昭和 37 年 4 月, 10 月本会講演大会にて発表 昭和37年10月 12 日受付

** 三菱鋼材株式会社深川製鋼所, 理博

*** 三菱銅材株式会社深川製鋼所 
Table 1. Element tabulation for steel analysis.

\begin{tabular}{|c|c|c|c|c|c|c|c|}
\hline \multirow{2}{*}{ Element } & \multirow{2}{*}{$\begin{array}{c}\text { Wave length } \\
(\AA)\end{array}$} & \multicolumn{2}{|c|}{$\begin{array}{c}\text { Analytical range } \\
(\%)\end{array}$} & \multirow{2}{*}{ Element } & \multirow{2}{*}{$\begin{array}{c}\text { Wave length } \\
(\AA)\end{array}$} & \multicolumn{2}{|c|}{$\begin{array}{c}\text { Analytical range } \\
(\%)\end{array}$} \\
\hline & & Spark & Arc & & & Spark & Arc \\
\hline $\begin{array}{l}\mathrm{P} \\
\mathrm{As} \\
\mathrm{B} \\
\mathrm{Cr} \\
\mathrm{Si} \\
\mathrm{Mn} \\
\mathrm{Al} \\
\mathrm{V} \\
\mathrm{Mo} \\
\mathrm{Sn}\end{array}$ & $\begin{array}{l}2149 \\
2288 \\
2496 \\
2677 \\
2881 \\
2933 \\
3082 \\
3102 \\
3132 \\
3175\end{array}$ & $\begin{array}{c}\bar{E} \\
\overline{-} \\
>0.01 \\
>0.04 \\
>0.01 \\
>0.015 \\
>0.001 \\
- \\
-\end{array}$ & $\begin{array}{l}<0.50 \\
<0.60 \\
<0.03 \\
<- \\
<0.10 \\
<0.15 \\
<\overline{-} 15 \\
<0.60\end{array}$ & $\begin{array}{l}\mathrm{Fe} \\
\mathrm{Cu} \\
\mathrm{Ti} \\
\mathrm{Zr} \\
\mathrm{Ni} \\
\mathrm{Fe} \\
\mathrm{Mo} \\
\mathrm{W} \\
\mathrm{Pb}\end{array}$ & $\begin{array}{l}3227 \\
3274 \\
3372 \\
3391 \\
3414 \\
3536 \\
3864 \\
4008 \\
4057\end{array}$ & $\begin{array}{c}\text { Standard } \\
>0.01 \\
>0.001 \\
>0.001 \\
>0.02 \\
>0.05 \\
>0.10 \\
>0.05\end{array}$ & $\begin{array}{c}\text { - } \\
\text { - } \\
\overline{-} \\
\text { Standard } \\
\overline{-} \\
<0.50 \\
<0.50\end{array}$ \\
\hline
\end{tabular}

Table 2. Element tabulation for slag analysis.

\begin{tabular}{c|c|c|c}
\hline \hline Element & $\begin{array}{c}\text { Wave length } \\
(\AA)\end{array}$ & $\begin{array}{c}\text { Analytical range }(\%) \\
\text { (Spark) }\end{array}$ \\
\hline $\mathbf{P}$ & 2149 & $\mathrm{P}_{2} \mathrm{O}_{5}: 10 \cdot 0 \sim 0 \cdot 015$ \\
$\mathrm{Si}$ & 2516 & $\mathrm{SiO}_{2}: 75 \cdot 0 \sim 10 \cdot 0$ \\
$\mathrm{Fe}$ & 2599 & $\mathrm{Fe}_{2}: 25 \cdot 0 \sim 0 \cdot 40$ \\
$\mathrm{Cr}$ & 2677 & $\mathrm{Cr}_{2} \mathrm{O}_{3}: 20 \cdot 0 \sim 0 \cdot 10$ \\
$\mathrm{Mg}$ & 2798 & $\mathrm{MgO}: 20 \cdot 0 \sim 0 \cdot 15$ \\
$\mathrm{Mn}$ & 2949 & $\mathrm{MnO}: 20^{\circ} 0 \sim 0 \cdot 20$ \\
$\mathrm{Al}$ & 3082 & $\mathrm{Al}_{2} \mathrm{O}_{3}: 25 \cdot 0 \sim 0 \cdot 30$ \\
$\mathrm{~V}$ & 3102 & $\mathrm{~V}_{2} \mathrm{O}_{5}: 5 \cdot 0 \sim 0 \cdot 01$ \\
$\mathrm{Ca}$ & 3158 & $\mathrm{CaO}^{\circ}: 70 \cdot 0 \sim 15 \cdot 0$ \\
$\mathrm{Ti}$ & 3372 & $\mathrm{TiO}_{2}: 8^{\circ} 0 \sim 0 \cdot 20$ \\
\hline
\end{tabular}

(3) 分析值はクロックダイヤルによつて時間記録方式 で示される. 従つて含有量とクロックダイヤル值との間 でえられる検量線の時間的ズレはすべて平行移動となる のでそれぞれの検量線に基ずいてクロックダイヤル中に 分析值を直接目盛つておくことができる。

(4) 粉状試料に対して回折格子の中心像 (Central Image）をも内標準1にできるようセットしてある.

(2) 分析元素

被分析可能元素ならびに使用スペクトル線は鋼および スラグの各被分析体に対して一応それぞれ Table 1 お よび 2 の通りであるがこれらのスペクトル線一光電管回 路は切変えスイッチにより任意に記録装置と組合せるこ とができるので，それぞれの使用スペクトル線は必要に 応じて任意に追加または変更できる仕組になつている.

\section{III. 鉄鋼試料に対する適用}

（1）発光方式の選択

ダイレクトリーダーを使用して実際の分析作業を行う に当つては分析精度を高めるために濃度によつてスパー クとアークの両発光方式を使い分ける必要がある. そこ で各元素ごとに各種浱度の試料を両方式で発光させてそ れぞれの記録値の繰返し精度を比較した。すなわちFig. 1 に示した $\mathrm{Si}$, Mo および $\mathrm{Cr}$ の各場合孛例にとつて

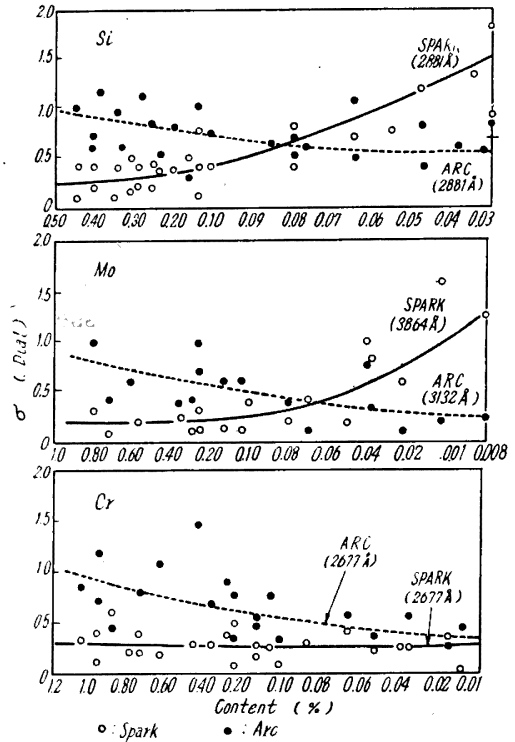

Fig. 1. Results of precision test on spectrochemical analysis of iron or steel.

見ると， Si では 0.08\%，Mo では 0.07\%を境にして これらの濃度以上ではスパーク発光が, またこれらの濃 度以下ではアーク発光がそれぞれ良い精度をえているこ と，一方 Crでは浱度が $0.01 \%$ 以上である限りスパー ク発光の方がアーク発光よりすべて良い精度を保持して いることがわかつた．以上のような検討を各元素につい て行つた結果，鉄鋼の分析に際しては Table 1 に併示 したようなスペクトル線を使用しかつそれぞれの元素濃 度による発光方式の使い分けを行うこととした。

（2）マトリックス効果に対する処置

発光分光分析作業は試料を一定の条件で発光させ，発 光スペクトルの内より内標準用スペクトル線強度とある 波長の被分析元素のスペクトル線強度とを比較して定量 を行うのが普通である，従つてこのためには 
(1) スペクトル線強度がこのスペクトル線を放射する 放電コラム中の原子数（またはイオン数）に常に比例し ている.

(2) 試料より放電コラム中に蒸発する瞬間比率が常に あらゆる含有原子(またはイオン)について一定である. が条件づけられる．ところでこれらの条件は光学的な事 柄を除くこスペクトル線強度の時間的変化が試料の組成 が集合状態，成分元素の組合せ，大きさおよび形状などに よつて差を示してはいけないことを意味している.とこ ろで発光に伴つて試料中の物質が蒸発気化する過程では 同時に試料中での搪散現象や界面における化学反応など も惹起されるために決して変化曲線が同類の物質であつ ても類似形をなさない場合が生じてくる筈である2〜4). そこで各種の鉄鋼試料を同一装置によつて分析するに当 つてはこ机らのマトリックス効果をどのように処理する かが重要な課題となるので先ず日常取り报う可能性のあ る代表的な各種試料を選 んで発光条件との関係を調べ た。

ここで試料のマトリックス効果は分析線対を变えるこ とによつて特定の項目については解消できると言われて いる556)。しかしダイレクトリーダーのような直読式で は測光可能なスペクトル線が予め最小限にセットされて

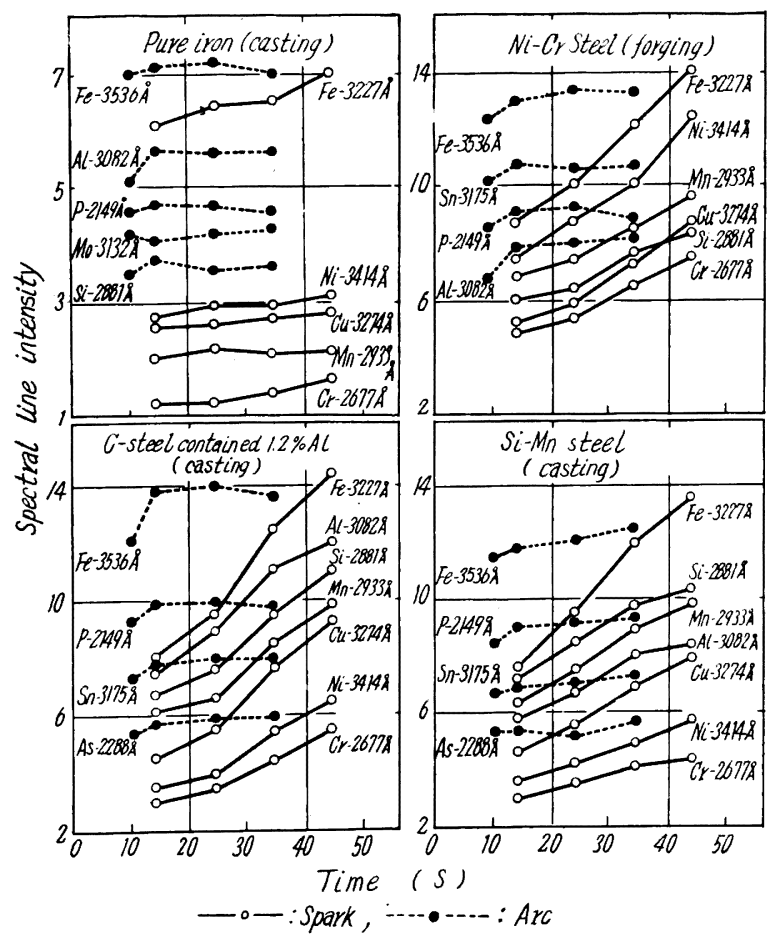

Fig. 2. Spectral line intensity curves.
あるため試料によつて分析線対を今さら変えるようなこ とは不可能に近い。 そこで固定された分析線対を対象に した場合のマトリックス効果をみるために先ず代表的な 試料を選んでそれぞれのスペクトル線強度一時間曲線を もとめた．その結果を示す Fig. 2 をみるとアーク発光 の場合は初期の $10 \mathrm{~s}$ 位に若干いちじるしいスペクトル 線強度の変化が認められたがその後はほとんど発光が継 続しても強度には変化が現れなかつた，一方スパーク発 光の場合をみると一般に発光が継続するにともなつてス ペクトル線強度もまた大きくなる傾向を認めたが，定量 的にみると元素の種類によつてその強度变化率が異なる ばかりか試料ごとでもその変化率に相当の差を示すこと がわからた。

このようにスパーク発光時に類似形の曲線がえられな い原因は当然分別蒸発作用の差によつて発光ガス組成が 変化することおよび発光にともなう温度変化がスペクト ル線強度に影響をおよぼすことに帰結すると考光られた がダイレクトリーダーによる発光分析においては

$$
t=R C \operatorname{In} V_{\mathrm{S}} / V_{\mathrm{X}}
$$

$V_{\mathrm{S}}:$ 内標準元素のスペクトル線強度

$V_{\mathrm{X}}:$ 被分析元素のスペクトル線強度

に基ずいてクロックダイヤルの回転時間によつて分析值 が記録されるようになつている．従つて上記のス ペりトル線強度一時間曲線のズレも上式にそう入 した場合に誤差程度にとどまるものであれば一応 問題外にして良いし，また逆にこれらの諸影響度 を誤差範囲にとどめる発光条件を見つけることが 発光分析法を適用できる必要条件ともなるわけで ある・ただし従来の化学分析法が長い間の研究に もかかわらず分析法を一本に統一できずにいるこ とを考えると現状の発光分析技術で共存元素なら びに治金履歴の影響度などを一様に解消できる発 光条件が見出せるとは必ずしも考えられないの でこの場合には試料により発光条件を変えた り7) 9)検量線を別々に作成しておく10) 11) のもや むをえないこととなろう。

そこでつぎに治金履歴, 共存元素の種類および 含有量を異にする種々の試料を発光条件を変えて スパーク発光させ，それぞれの発光条件について 検量線よりえた值を化学分析值と比較してみた。 Fig.3はこのようにしてえた Si および Mn 分 析值の精度と発光条件との関係を示したものであ つて, マトリックス効果の影響度は発光強度をた かめる程また予備放電時間を長くするほど小にで 


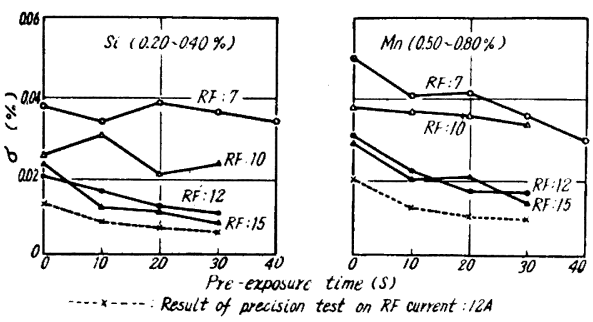

Fig. 3. Precision test of analytical result with various spark discharge.

きた。すなわち装置自体の性能（繰返し精度：図中に破 線で示す）と対比させて見ると $R F$ 電流を $12 \mathrm{~A}$ 以上予 備放電時間を $10 \mathrm{~s}$ 以上にした場合には同一発光条件お よび同一検量線で各種試料の分析が可能なように充分予 測できたので以下

$$
\begin{aligned}
\text { スパーク }: & \text { 一次電流 }: 8 \cdot 2 \mathrm{~A}, R F \text { 電流 }: 12 \cdot 0 \mathrm{~A} \\
& \text { 予備放電 }: 20 \mathrm{~s}, \text { 本放電 }: 23 \mathrm{~s} \\
\text { アーク }: & \text { 一次電流 }: 4 \cdot 2 \mathrm{~A} \\
& \text { 予備放電 }: 5 \mathrm{~s}, \text { 本放電 }: 15 \mathrm{~s}
\end{aligned}
$$

の発光条件を使用して日常しばしば取扱う各種試料の分 析精度をチエックした。

まず鉄鋼分光分析作業の基幹をなす炉前試料では採取 に当つて鎮静用として Al を添加しているが，この $\mathrm{Al}$ 含有量が他の元素の分析結果に打よぼす影暗は非常に注 視しなければならないと言水机ている12)。そこで A1 添 加量をいろいると変えて採取した炉前試料について分光 分析結果と化学分析值と比較した処 Fig. 4 にみるごと $<\mathrm{Al}$ 含有量 $1.0 \%$ 以下では両分值間に器械自体の繰 返し精度以上の差がほ上えど生じないこ上を確認でき た。

なお炉前試料採取に当つては通常鋼製の鋳型老使用し ているふ採取した試料に湯張りを生ずるなよ゙の欠点があ つたため煉瓦鋳型の併用を考虑したところでこの場合 には両試料間に冷却速度の遅速に基ずくマトリックス効 果が生ずることも考えられたので炭秦鋼および $\mathrm{Mn}-\mathrm{Cr}$ 鋼を対象に上記発光条件で比較分析を行つたが結果は

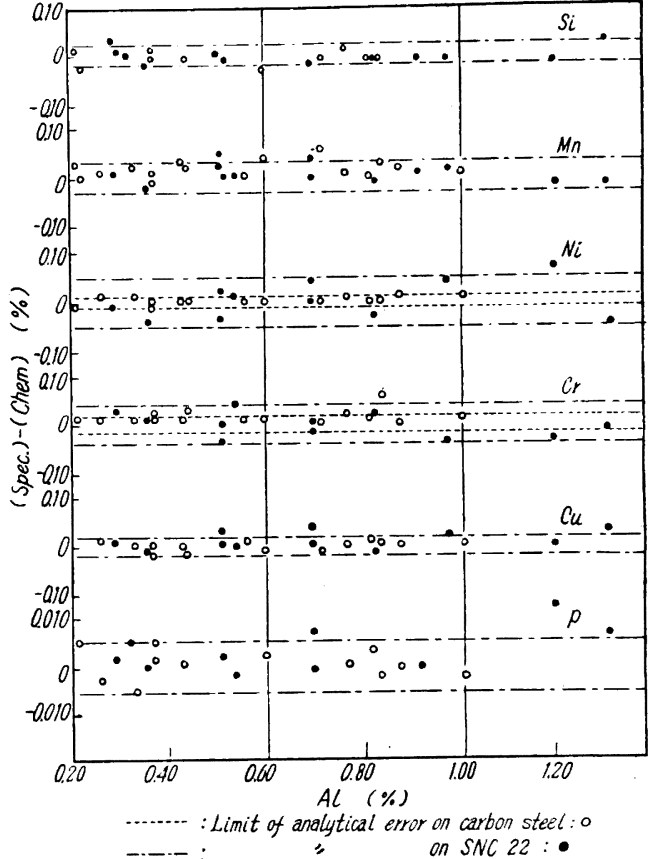

Fig. 4. Effect of Al in sample on spectrochemical value.

Table 3 に灭るごとくすべての元素において全く有意差 がなかつた。

一方治金履歷の異なる鋳造試料と鉒造試料との差を合 金鋼文対象に比較すると Table 4 となり同様両分析值 間の差涽滴出来なかつた，従つて予測通り日常取扱う 程度の鍛造試料はとくに別個な標準を規定しなくても鋳 造試料と一緒に分析が可能となつた。

ここでダイレクトリーダーによる発光分析用試料は径 （又は一辺の長さ） $30 \mathrm{~mm}$ 以上と規定したが，実際の被 発光面栍は最大で径 $10 \mathrm{~mm}$ であるからこれ以上の面積 を有する試料はいずれも正常条件で発光分析が可能であ る.ところで日常の作業分析においては上記以下の面積

\begin{tabular}{|c|c|c|c|c|c|c|c|c|c|c|}
\hline $\begin{array}{l}\text { Kind of } \\
\text { steel }\end{array}$ & & $\begin{array}{l}\mathrm{Si} \\
(\%)\end{array}$ & $\begin{array}{l}\mathrm{Mn} \\
(\%)\end{array}$ & $\underset{(\%)}{\mathrm{P}}$ & $\begin{array}{l}\mathrm{Ni} \\
(\%)\end{array}$ & $\begin{array}{l}\mathrm{Cr} \\
(\%)\end{array}$ & $\begin{array}{c}\mathrm{Cu} \\
(\%)\end{array}$ & $\begin{array}{l}\mathrm{Sn} \\
(\%)\end{array}$ & $\begin{array}{c}\text { As } \\
(\%)\end{array}$ & $\begin{array}{c}\mathrm{A} 1 \\
(\%)\end{array}$ \\
\hline C- & $\begin{array}{c}\bar{X} \\
\text { Std. dev. }\end{array}$ & $\mid \begin{array}{l}0 \cdot 00077 \\
0 \cdot 0040\end{array}$ & $\left|\begin{array}{l}0 \cdot 00231 \\
0 \cdot 012\end{array}\right|$ & $\left|\begin{array}{l}0 \cdot 000307 \\
0 \cdot 0016\end{array}\right|$ & $\mid \begin{array}{l}0 \cdot 00077 \\
0.0038\end{array}$ & $\left|\begin{array}{c}-0 \cdot 000385 \\
0 \cdot 0020\end{array}\right|$ & & $5 \cdot 0 \cdot 000$ & $5 \mid \begin{array}{l}0 \cdot 0005 \\
0 \cdot 0026\end{array}$ & $\begin{array}{c}-0.000038 \\
\cdot 0.00019\end{array}$ \\
\hline 1 & $\begin{array}{c}\bar{X} \\
\text { Std. dev. }\end{array}$ & $\begin{array}{l}0 \cdot 000083 \\
0 \cdot 0030\end{array}$ & $3\left|\begin{array}{l}0 \cdot 00417 \\
0 \cdot 0151\end{array}\right|$ & $\left|\begin{array}{l}0 \cdot 000917 \\
0 \cdot 00332\end{array}\right|$ & $\begin{array}{l}0 \cdot 000 \\
0 \cdot 003\end{array}$ & $\begin{array}{l}0.000834 \\
0.00313\end{array}$ & $\begin{array}{c}-0.000834 \\
0.00297\end{array}$ & $\begin{array}{c}40.000157 \\
0.00060\end{array}$ & $\left|\begin{array}{l}0 \cdot 00108 \\
0 \cdot 000392\end{array}\right|$ & $2 \begin{array}{c}-0.000417 \\
0.00149\end{array}$ \\
\hline
\end{tabular}
をもつ試料をも分析の対象にしなければならない場合が しばしば生ずる。そこでつきにこのような試料の取り扱

Table 3. Difference with the kind of mould on analytical result of casting steel.

$\bar{X}=\Sigma\{($ Steel mould $)-($ Brick mould $)\} / n$ 
Table 4. Difference between casting sample and forging sample on spectrochemical analysis.

\begin{tabular}{|c|c|c|c|c|c|c|c|c|}
\hline & & $\begin{array}{l}\mathrm{Si} \\
(\%)\end{array}$ & $\underset{(\%)}{\operatorname{Mn}}$ & $\underset{(\%)}{P}$ & $\begin{array}{c}\mathrm{Ni} \\
(\%)\end{array}$ & $\begin{array}{l}\mathrm{Cr} \\
(\%)\end{array}$ & $\begin{array}{l}\mathrm{Cu} \\
(\%)\end{array}$ & $\begin{array}{l}\text { Mo } \\
(\%)\end{array}$ \\
\hline $\mathrm{SCM} 3$ & $\begin{array}{c}\bar{X} \\
\text { Std. dev. }\end{array}$ & $\begin{array}{l}0 \\
0.00,305\end{array}$ & $\begin{array}{l}0.0042 \\
0.0218\end{array}$ & $\begin{array}{l}0.00072 \\
0.00263\end{array}$ & $\begin{array}{l}0.00162 \\
0.0079\end{array}$ & $\begin{array}{r}-0.0033 \\
0.0193\end{array}$ & $\begin{array}{l}\dot{0} \cdot 0022 \\
0 \cdot 0186\end{array}$ & $\begin{array}{l}0 \cdot 0025 \\
0 \cdot 0162\end{array}$ \\
\hline $\mathbf{S} \mathbf{N C}$ & $\begin{array}{c}\bar{X} \\
\text { Std. dev. }\end{array}$ & $\begin{array}{r}-0.0031 \\
0.0112\end{array}$ & $\begin{array}{r}-0.0035 \\
0.0123\end{array}$ & $\begin{array}{l}0 \cdot 000042 \\
0 \cdot 00147\end{array}$ & $\begin{array}{r}-0.0034 \\
0.0346\end{array}$ & $\mid \begin{array}{c}-0.00030 \\
0.0212\end{array}$ & $\begin{array}{l}0 \cdot 0017 \\
0 \cdot 0073\end{array}$ & \\
\hline S U P 6 & $\begin{array}{c}\bar{X} \\
\text { Std. dev. }\end{array}$ & $\begin{array}{r}-0.0045 \\
0.0352\end{array}$ & $\begin{array}{l}0.0007 \\
0.0231\end{array}$ & $\begin{array}{l}0 \cdot 000092 \\
0 \cdot 00187\end{array}$ & $\begin{array}{r}-0.0057 \\
0.0162\end{array}$ & $\begin{array}{l}0.0011 \\
0.0233\end{array}$ & $\begin{array}{r}-0.0027 \\
0.0194\end{array}$ & \\
\hline $\operatorname{SMn} 23$ & $\begin{array}{c}\bar{X} \\
\text { Std. dev. }\end{array}$ & $\begin{array}{l}0.0007 \\
0.0105\end{array}$ & $\begin{array}{l}0.00307 \\
0.0360\end{array}$ & $\begin{array}{r}-0.00040 \\
0.00262\end{array}$ & $\begin{array}{r}-0.0016 \\
0.0107\end{array}$ & $\begin{array}{l}0 \cdot 0046 \\
0 \cdot 0162\end{array}$ & $\begin{array}{l}0.0020 \\
0.0164\end{array}$ & \\
\hline
\end{tabular}

$\overline{\mathrm{X}}=\Sigma\{($ Casting $)-($ Forging $)\} / n$

い方法を径 $6 \mathrm{~mm}$ の試料を例に調べた.

すなわ台 $6 \mathrm{~mm}$ ゆ の試料では正常な発光を行うのに 必要な面積がない，従つて発光にともなうスペクトル線 強度は当然正常条件の場合に比べて小に年筈であつて このことはFe-3こ2ュAの強度測定においても約 5\%減と して確認できた。ところて単に発光面皘の隇少だけに結 果が集約されるならげすべてのスペクトル線强度は相対 的な減少のみにとよ゙まるため記録值自体には洼とんど差 を生じない筈であるか，この場合に試料サイズの影響な

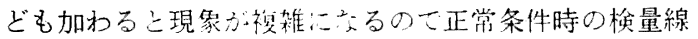
と注全く別個な渙量線考考える必要主生じてくる. Fig. 5 はこの意味より理々沙度の $6 \mathrm{~mm} \oint$ 試料空使用して无 た検量線を正常条件下のもの上此較したものてあるが， 両者の差は、ずれの元素に执いても平行的なズレのみに とどまつた，従つて径（志だ泣一梁の長さ）10 mm以下 の試料に対しては同形同容稓の標準試料总使用してク口 ックダイヤルの目盛のズレ蓄調整（実際にはクロックダ イヤル中に分析值が目盛つてあるのて目盛盤の指針と分 析值が合うよう回転させると良い)しておきさえすれば

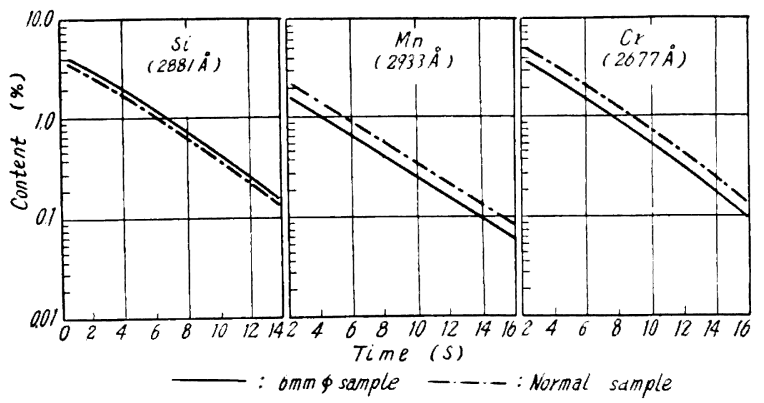

Fig. 5. Working curves of $6 \mathrm{~mm} \oint$ sample in comparison with these of normal sample on spectrochemical analysis of iron or steel.
正常条件での目盛盤がそのまま適用できることとなつ t.

\section{IV. スラグ試料に対する適用}

（1）分析法の選定

スラグのような粉状物質を迅速に処理する方法として

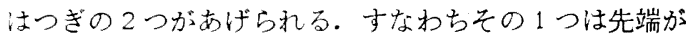
カップ状になつている炭素電極中に粉状の試料を押还え て直接発光させる粉末法111314) であつて試料の製作に時 間要し要しい反面発光と共に試料が飛散して装置内部を いちじるしく污す知点をもつている. 今1つのブリケッ ト法は粉状の試料をC 粉末と一定の割合に混合しペレッ ト状にプレスして発光させるもので15)試料内部の偏析の 影響志除くために回転発光などの工夫も加えられている が，迅速法として前者と比較した場合試料の製作に相当 時間定费す欠点がある。

このよう汇上記の2 万法はそれぞれ一長一短があつて Analytical technique ふらだけでは優劣を決めかねた ので発光条件を大体同じにして比較実験を行つた処 Table 5 の結思志えた。すなわち分析精度の面よ り見るとA㧍よびBの粉末法注シャッターの条件 にかかわらず $\mathrm{Fe}, \mathrm{Ca}$ および $\mathrm{Si}$ のごとき主要 元素においてCのブリヶット法よりいちじるしく 劣ることがわかつたそここでスラグの迅速分析に は多少時間を要してもブリケット法が適している こととなつたので，つきにこの場合の試料作成法 おょび発光条件などに対してさらに細かい検討を 加光た。

先ずペレット状にする試料の粒度と分析精度と の関倸を調べると Table 6より粒子が細かくな る程試料間のばらつきは小さ、くかつ同一試料内で 
の絽返し記録精度も向上 するが， $\mathrm{Fe} ， \mathrm{Ca}$ および Si のみを分析の対象に した場合（炉前迅速分析 の主なケース）には 100 mesh 程度の粒子でも充 分好精度を記録できる見 通しをえた。

一方発光条件としては 予備放電時間が一番重要 な要素となるが，その影 踣度は Fig. 6 にみるご とく予備放電が短い程良 い繰返し 精度をえてお り, 丁度先の鉄鋼試料の

\begin{tabular}{|c|c|c|c|c|}
\hline \multicolumn{2}{|c|}{ Method } & A & B & C \\
\hline \multicolumn{2}{|c|}{ Sample } & $\begin{array}{c}\text { Powder } \\
(200 \text { mesh })\end{array}$ & $\begin{array}{c}\text { Powder } \\
(200 \text { mesh })\end{array}$ & $\begin{array}{c}\text { Pellet } \\
(\mathrm{C}: \text { Sample }=10: 3)\end{array}$ \\
\hline \multicolumn{2}{|c|}{$\begin{array}{ll}\text { Pre-exposure time } & \text { (S) } \\
\text { Exposure time } & \text { (S) } \\
\text { Shutter } & \\
\text { Primary current } & \text { (A) } \\
\text { RF current } & \text { (A) }\end{array}$} & $\begin{array}{c}0 \\
23 \\
\text { Normal } \\
8 \cdot 6 \\
7 \cdot 0\end{array}$ & $\begin{array}{c}0 \\
15 \\
\text { Open } \\
8 \cdot 6 \\
7 \cdot 0\end{array}$ & $\begin{array}{c}0 \\
23 \\
\text { Normal } \\
8 \cdot 6 \\
7 \cdot 0\end{array}$ \\
\hline $\begin{array}{l}\text { Std. dev. } \\
\text { (clock dial) }\end{array}$ & $\begin{array}{l}\mathrm{Si} \\
\mathrm{Mn} \\
\mathrm{P} \\
\mathrm{Mg} \\
\mathrm{Cr} \\
\mathrm{Ca} \\
\mathrm{Fe} \\
\mathrm{Al} \\
\mathrm{Ti}\end{array}$ & $\begin{array}{l}0 \cdot 40 \\
0.44 \\
2 \cdot 65 \\
0 \cdot 25 \\
1 \cdot 73 \\
0 \cdot 50 \\
0 \cdot 36 \\
0.97 \\
0.48\end{array}$ & $\begin{array}{l}0 \cdot 38 \\
0 \cdot 55 \\
2 \cdot 23 \\
0 \cdot 74 \\
1 \cdot 69 \\
0 \cdot 72 \\
0 \cdot 22 \\
0 \cdot 45 \\
0 \cdot 51\end{array}$ & $\begin{array}{l}0 \cdot 28 \\
0 \cdot 62 \\
0 \cdot 92 \\
0 \cdot 96 \\
1 \cdot 33 \\
0 \cdot 22 \\
0 \cdot 17 \\
0 \cdot 29 \\
0 \cdot 42\end{array}$ \\
\hline
\end{tabular}

場合とは逆の結果となつた．このことは発光にともなつ て試料の表面がいちじるしく損耗するため発光が長びく と発光間隙が不規則に変つて精度の面に影響をもたらす あのと考えられたのでこの種の試料に対してはあらかじ め表面を注意して平滑にする代り予備放電時間を無しに した.

Table 6. Result of precision test with the particle size on slag analysis.

\begin{tabular}{|c|c|c|c|c|c|c|}
\hline \multirow[t]{2}{*}{ Element } & \multicolumn{3}{|c|}{$\begin{array}{l}\text { Variation on a } \\
\text { sample } \\
\text { (clock dial) }\end{array}$} & \multicolumn{3}{|c|}{$\begin{array}{l}\text { Variation with } \\
\text { sample } \\
\text { (clock dial) }\end{array}$} \\
\hline & $\begin{array}{c}50 \\
\text { mesh }\end{array}$ & $\begin{array}{c}100 \\
\text { mesh }\end{array}$ & $\begin{array}{c}200 \\
\text { mesh }\end{array}$ & $\begin{array}{c}50 \\
\text { mesh }\end{array}$ & $\begin{array}{c}100 \\
\text { mesh }\end{array}$ & $\begin{array}{r}200 \\
\text { mesh }\end{array}$ \\
\hline $\mathrm{Fe}$ & $2 \cdot 5$ & 0.3 & $0 \cdot 7$ & $7 \cdot 3$ & $1 \cdot 6$ & $0 \cdot 6$ \\
\hline $\mathrm{Ca}$ & $0 \cdot 8$ & $1 \cdot 0$ & $1 \cdot 5$ & $3 \cdot 1$ & 0.2 & 0.5 \\
\hline $\mathrm{Si}$ & $1 \cdot 7$ & 0.4 & 0.3 & $2 \cdot 5$ & $1 \cdot 3$ & 0.4 \\
\hline $\mathrm{Mn}$ & $5 \cdot 2$ & $1 \cdot 8$ & $1 \cdot 4$ & $2 \cdot 0$ & $4 \cdot 6$ & $1 \cdot 3$ \\
\hline$P$ & $7 \cdot 9$ & $1 \cdot 1$ & 1.0 & 0.9 & $2 \cdot 2$ & 2.5 \\
\hline $\mathrm{Cr}$ & $5 \cdot 0$ & $1 \cdot 8$ & $1 \cdot 3$ & $0 \cdot 4$ & 0.4 & $1 \cdot \varepsilon$ \\
\hline A1 & $1 \cdot 5$ & 0.7 & $=0$ & $1 \cdot 1$ & $3 \cdot 3$ & $0 \cdot 4$ \\
\hline V & $3 \cdot 3$ & $1 \cdot 5$ & 0.9 & $1 \cdot 4$ & $1 \cdot 2$ & $1 \cdot 2$ \\
\hline$T_{i}$ & $1 \cdot 8$ & $3 \cdot 0$ & 0.8 & $1 \cdot 7$ & $2 \cdot 3$ & $1 \cdot 0$ \\
\hline $\mathrm{Mg}$ & 2.9 & $1 \cdot 2$ & $0 \cdot 6$ & $5 \cdot 7$ & $4 \cdot 3$ & $1 \cdot 4$ \\
\hline
\end{tabular}

Table 7. Result of precision test with the condition of discharge on slag analysis.

\begin{tabular}{c|c|c|c|c|c}
\hline \hline $\begin{array}{c}\text { Element } \\
\text { (content) }\end{array}$ & $\mathrm{Fe}_{2} \mathrm{O}_{3}$ & $\begin{array}{c}\mathrm{CaO} \\
(7 \cdot 0 \%)\end{array}$ & $\begin{array}{c}\mathrm{SiO}_{2} \\
(46.0 \%)\end{array}$ & $\begin{array}{c}\mathrm{P}_{2} \mathrm{O}_{5} \\
(28 \% \%)\end{array}$ & $\begin{array}{c}\mathrm{MgO} \\
(0.06 \%)\end{array}$ \\
\hline $\begin{array}{c}\text { Spark } \\
(\mathrm{RF}: 7 \cdot 0)\end{array}$ & 0.40 & 0.5 & 0.8 & 0.0065 & 0.08 \\
$\begin{array}{c}\text { Spark } \\
(\mathrm{RF}: 10.0)\end{array}$ & 0.39 & 0.8 & 1.8 & 0.0080 & 0.06 \\
$\begin{array}{c}\text { Spark } \\
(\mathrm{RF}: 12.0)\end{array}$ & 0.71 & 2.1 & 1.9 & 0.0060 & 0.06 \\
Arc & 0.27 & 1.6 & 0.5 & 0.017 & 0.10 \\
\hline
\end{tabular}

ところで同様な現象は発光強度に関しても認められ た. すなわち上記の諸検討はすべて Table 5 のC法に 従つて行つたが，スラグのような広浱度範囲のブリケッ 卜試料に種々の発光条件を適用させてみた結果では Table 7 に示すように同じ理由によつて発光強度が強く なる程分析精度が低下しかつ試料の破損率も高くなる傾 向があつた．なおこの結果によると低濃度領域を分析す る際にはアーク発光がむしろ分析精度の点でスパーク発 光の結果より悪かつた. 従つてスラグの濃度範囲では鉄 鋼試料の場合のような浱度による発光方式の使い分けは 不必要であつて, 1 つの発光条件（Table 7 より前記 C

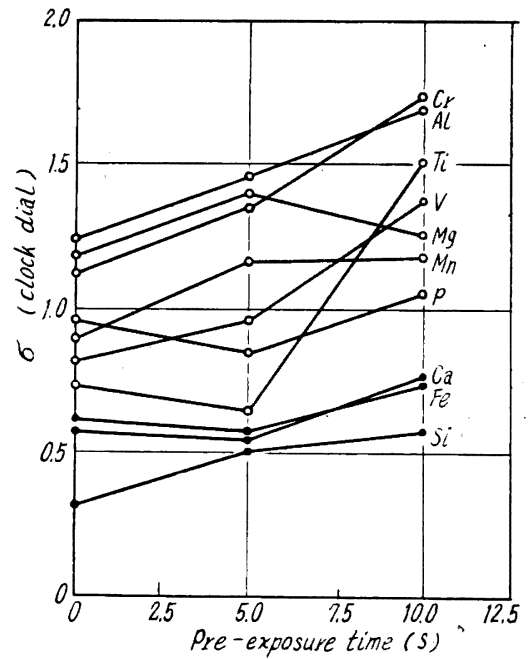

Fig. 6. Effect of pre-exposure time on recording value of slag sample prepared with briquetting technique. 
法の発光条件が最適）で全元素の分析を行うのがむしろ 妥当な事も確奴ことができた.

\section{（2）娭量線の作成}

スラグ分析の対象にしたのは塩基性電気炋㳯であつた が, 検量図の作成に当つてはその他の各種スラグも分析 可能なようにてさるただ浱度範围を拡げるようにつとめ た．とこちで各酸化物の検量図作成に際しては各種搌度 の標準試料を必要とするため塩基性電灯㳯だけでは充分 ではなかつた，そこでクリプトル炉志使用して任意組成 のスラグを合成すると共に他社より異なつたスラグを譲 り受けたがこれだけでもな抢不充分だつたのでさらに稀 釈試料をも加えた。この稀釈試料とはC 粉末と配合する 試料の割合を適宜他の純粋酸化物で稀釈したものであつ て, あらかじめ $\mathrm{Fe}_{2} \mathrm{O}_{3}$ の低浱度領域に対して適用を試 みた結果は Fig. 7 のごとく純粋なスラグ試料と同等に 取扱えることを確認したので，この試料の併用によつて 標準試料を持ち台せない浱度領域の検量図が作成できる

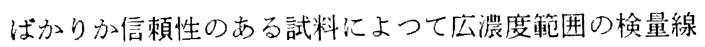
もチェックできることとなつた. つきに Fig. 8 として これらの各種試料を併用してえた酸化物としての $\mathrm{Fe}$, $\mathrm{Ca}$ および $\mathrm{Si}$ の各恰量図を示す.

なおスラグ中含有元素の各椧量線の内で $\mathrm{Fe}$ の検量線 の子は図に見る通り2本に分けられ, 塩基性電気炉滓に 注目した場合酸化期滓と還元期㳯とで検量線が異つた。 このことは発光分析法自体があくまでも元素浱度の測定 であるためスラグ中での形態が一定している Ca および Si の上うな元素では発光にともなう励起状態に試料ご との差を生し就が， $\mathrm{Fe}$ のように $\mathrm{FeO}$ と $\mathrm{Fe}_{2} \mathrm{O}_{3}$ の 2 形態がある元素では試料中の形態によつて励起されるエ ネルギー準位に差志生じ，この差が少くとも検量線花複 数にする原因の1つをつくるもの上解釈されよう.

\section{V. 分析作業管理方式}

ダイレクトリーダーのような自動式装置による分析作 業では湿式分析法に比べて人為的な䛊差を生ずる可能性 が非常に少になるが決して皆無になるとは言えない反面 器械および試料自体などの不良に基ずく誤差も逆に生ず る可能性がある・ところでこれらの誤差をできるだけ小 にして良好な分析精度を維持してりくには日常の分析作 業時に㴊重かつ適切な管理方式を適用してゆく以外に途 はない。すなわち本分析作業において想定できる誤差要 因としては
(1) 試料の状態
(2) 標準試料の分析值
(3) 発光条件

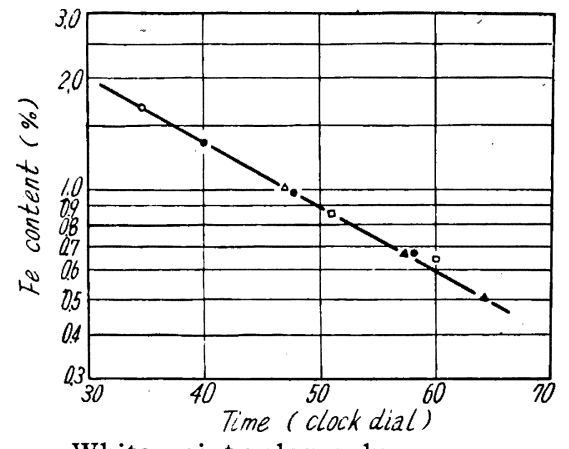

White point: slag only Dark point : slag diluted by pure calcium oxide

Fig. 7. Working curve for $\mathrm{Fe}_{2} \mathrm{O}_{3}$ in briquetting sample.

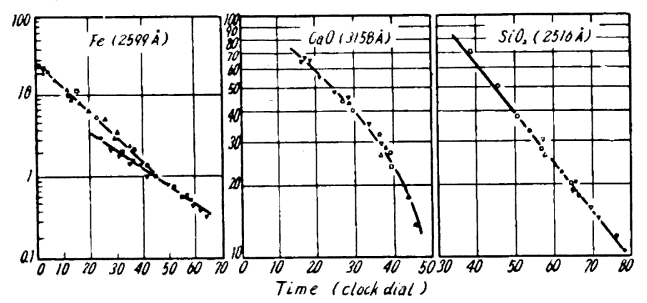

$\triangle$ : Oxidizing slag in steelmaking process with a $\triangle$ : Oxidizing slag in steelmakin

$\nabla$ : Reducing slag

$\square$ : Slag in ferroalloy making process

$O$ : Synthetic slag

Dark point : sample diluted by a pure oxide

Fig. 8. Working curves for slag analysis.

(4) Standardization

などろ゙南げられるがこれらに対して適用してきた管理方 式を示すとつぎのごとくである.

1. 湿式法による管理分析

湿式法を用いて抜取り方式で分光分析值をチェックす ると共に, 新しい標準試料を使用し始める場合には分光 および湿式の両分析法を相当数の試料に対し併用して慓 準試料の分析値の正確度を調べる.すなわち Table 8 は 過去 1 力年間に $\mathrm{Mn}-\mathrm{Cr}$ 鋼の標準試料を代えた 3 度の調 査記録であつて，先ず主要元素についてそれぞれ両分析 法による值の差を解析し, 1 回目の $\mathrm{Mn}$ および $\mathrm{Cu}$, 3 回目の Mn および $\mathrm{Ni}$ のように両分析值間に有意差 を生じた元素に対しては標準試料の分析值をそれぞれ修 正してふたたび分析值の比較を行い，この標準試料の分 析值を適用しても有意差が生じない事を確認した後始め て標準試料の交換を行つている.

\section{2.内標準スペクトル線強度の管理}

分光分析值は被分析用スペクトル線と内標準用スペク トル線の強度比より求めている. 従つて分析条件が非正 
Table 8. Results of chemical cheçk for standard sample.

\begin{tabular}{|c|c|c|c|c|c|c|c|}
\hline & & $\mathrm{Si}$ & $\mathrm{Mn}$ & $P$ & $\mathrm{Ni}$ & $\mathrm{Cr}$ & $\mathrm{Cu}$ \\
\hline I & $\begin{array}{l}n \\
\triangle\end{array}$ & $\begin{array}{c}20 \\
-0 \cdot 0035\end{array}$ & $\begin{array}{c}20 \\
-0.0070 \\
0.0043\end{array}$ & $\begin{array}{c}20 \\
0 \cdot 000053\end{array}$ & $\begin{array}{c}20 \\
-0 \cdot 00408\end{array}$ & $\begin{array}{c}20 \\
-0 \cdot 00855\end{array}$ & $\begin{array}{l}20 \\
-0 \cdot 0152 \\
-0.0037\end{array}$ \\
\hline $\mathbb{I}$ & $\begin{array}{l}n \\
\triangle\end{array}$ & $\begin{array}{c}20 \\
0 \cdot 0018\end{array}$ & $\begin{array}{c}20 \\
0 \cdot 00441\end{array}$ & $\begin{array}{c}20 \\
0 \cdot 000092\end{array}$ & $\begin{array}{c}20 \\
-0 \cdot 0035\end{array}$ & $\begin{array}{c}20 \\
0 \cdot 00226\end{array}$ & $\begin{array}{l}20 \\
-0 \cdot 0026\end{array}$ \\
\hline III & $\begin{array}{l}n \\
\triangle\end{array}$ & $\begin{array}{c}20 \\
-0 \cdot 0021\end{array}$ & $\begin{array}{c}20 \\
0 \cdot 0124 \\
0 \cdot 0048\end{array}$ & $\begin{array}{c}20 \\
0 \cdot 0000108\end{array}$ & $\begin{array}{c}20 \\
0.0137 \\
-0.0019\end{array}$ & $\begin{array}{c}20 \\
-0 \cdot 000303\end{array}$ & $\begin{array}{c}20 \\
-0 \cdot 00085\end{array}$ \\
\hline
\end{tabular}

$\triangle=\Sigma($ Chem. - Spec. $) / n$

Table 9. Variations of analysed value with the condition of discharge.

\begin{tabular}{|c|c|c|c|c|c|c|c|}
\hline Discharge & Condition & $\underset{(\%)}{\mathrm{Si}}$ & $\begin{array}{l}\mathrm{Mn} \\
(\%)\end{array}$ & $\begin{array}{l}\mathrm{Ni} \\
(\%)\end{array}$ & $\begin{array}{l}\mathrm{Cr} \\
(\%)\end{array}$ & $\underset{(\%)}{\mathrm{Cu}}$ & $\begin{array}{l}\mathrm{Fe}-3227 \AA \\
\text { (Voltage) }\end{array}$ \\
\hline Spark & $\begin{array}{l}\quad \text { Normal } \\
\quad \text { Gap spacing }: 2 \mathrm{~mm} \\
\text { Angle of carbon electrode }: 120^{\circ} \\
\text { R.F current }: 10^{\circ} \mathrm{A} \\
\text { Pre-exposure time }: 10 \mathrm{~s} \\
\text { Unsound ssmple }\end{array}$ & $\begin{array}{l}0 \cdot 26 \\
0 \cdot 23 \\
0 \cdot 23 \\
0 \cdot 38 \\
0 \cdot 30 \\
0 \cdot 25\end{array}$ & $\begin{array}{l}0 \cdot 90 \\
0 \cdot 66 \\
0 \cdot 73 \\
0 \cdot 92 \\
0 \cdot 94 \\
0 \cdot 78\end{array}$ & $\begin{array}{l}0 \cdot 09 \\
0 \cdot 10 \\
0 \cdot 11 \\
0 \cdot 19 \\
0 \cdot 10 \\
0 \cdot 12\end{array}$ & $\begin{array}{l}0 \cdot 78 \\
0 \cdot 67 \\
0 \cdot 67 \\
0 \cdot 80 \\
0 \cdot 89 \\
0 \cdot 75\end{array}$ & $\begin{array}{l}0 \cdot 20 \\
0 \cdot 21 \\
0 \cdot 23 \\
0 \cdot 39 \\
0 \cdot 19 \\
0 \cdot 22\end{array}$ & $\begin{array}{l}15 \cdot 0 \\
12 \cdot 3 \\
14 \cdot 1 \\
11 \cdot 8 \\
13 \cdot 8 \\
14 \cdot 2\end{array}$ \\
\hline Discharge & Condition & $\underset{(\%)}{\mathrm{P}}$ & $\begin{array}{l}\mathrm{Sn} \\
(\%)\end{array}$ & $\underset{(\%)}{\text { As }}$ & $\begin{array}{c}\mathrm{A} 1 \\
(\%)\end{array}$ & & $\begin{array}{l}\mathrm{Fe}-3536 \AA \\
\text { (Voltage) }\end{array}$ \\
\hline Arc. & $\begin{array}{l}\text { Normal } \\
\text { Gap spacing : } 3 \mathrm{~mm} \\
\text { Angle of carbon electrode : } 160^{\circ} \\
\text { Pre-exposure time : O s } \\
\text { Unsound sample }\end{array}$ & $\begin{array}{l}0 \cdot 028 \\
0 \cdot 045 \\
0 \cdot 055 \\
0 \cdot 042 \\
0 \cdot 062\end{array}$ & $\begin{array}{l}0.025 \\
0.026 \\
0.031 \\
0.029 \\
0.095\end{array}$ & $\begin{array}{l}0.029 \\
0.025 \\
0.031 \\
0.036 \\
0.038\end{array}$ & $\begin{array}{l}0 \cdot 007 \\
0 \cdot 007 \\
0 \cdot 010 \\
0 \cdot 005 \\
0 \cdot 053\end{array}$ & & $\begin{array}{r}9 \cdot 1 \\
12 \cdot 3 \\
11 \cdot 1 \\
7 \cdot 8 \\
9 \cdot 7\end{array}$ \\
\hline
\end{tabular}

常であつたために分析値に䛊りを生ずるようなケースで は少くとも内標準用スペクトル線の強度に異常を認的得 る筈であるこの事実を確以るためにつぎ分析条件中 で日常生ずる可能性のあるエラーを故意に設けて発光し た場合の分析值および内標準スペクトル線強度を正常時 と比較したところが鉄鋼分析の場合に Table 9 のよう 就果をえた。すなわち少くとも分析值に誤差を生ずる ような発光条件では内標準用スペクトル線強度も正常時 に比べていちじるしく異なることがわかつたので，日常 の分析作業時においては常に内標準用スペクトル線強度 を同時に記録し，万一この值に異常它認めた場合には分 析条件にエラーがあるものと見て諸条件を調べると共に 前回の分析値を捨てて再分析を行うことにしている.

3. Standardization の状況管理

分析精度を維持するためには Standardization によ つて検量線の位置のズレを適宜調整する必要がある．所 でダイレクトリーダーには Automatic Servo Monitor と称する器械が付属していて回折格子と射出スリットと の相対位㯰のズレを自動的に調節できるようになつてい
るので Standardization の手間は他のこの種の装置の 場合に比べ相当はら゙けると言われてきた。 そこで先ずこ の Monitor の機能のみに頼つて全然 Standardization を行なわなかつた場合に生ずる検量線の位置のズレを 1 週間にわたつて調べたところ Fig.9 の結果を得た。す なわち図では横軸に時間を縦軸にクロックダイヤル值お よび分析值をとつて炭素鋼中の主要元素についての推移 を記録したか，検量線のズレおよびそれにともなう分析 值の誤差には顕著な变動が認められず少くとも Standardization 後 $24 \mathrm{~h}$ 以内の変動咳械自体の繰返し記 録精度(鎖線の範用)内に止まつていることがわかつた。 従つて Standardization は作業員の交代時に念のため 行う程度に止め. その代り Monitor の機能をたえずチ エックして正常な作動状態にこの器械を保持するようつ と的ることした。

ここで Standardization に際してはクロックダィヤ ルの位置を正しく調整する必要がある。そこで Standardization を行つた場合にはその調整位置を Fig.9の 様式の管理図中に記録してチエック寸ると共に，万一前 


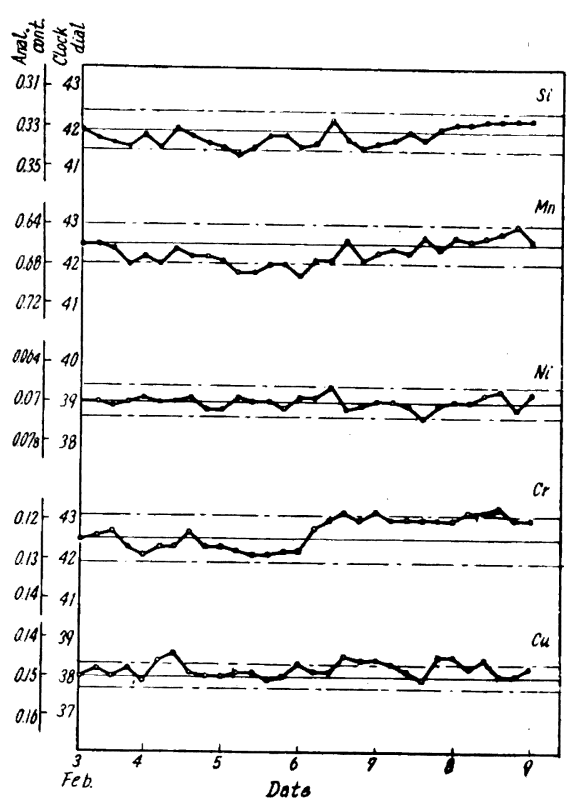

Fig. 9. Trends of analytical value under the condition of non-standardization.

回に比べ位置にかなりの变化生をじた場合には他の標準 試料を加えてその調整位置の良否を確認する方式も併用 した。

\section{VI. 結言}

ダイレクトリーダーを低合金鋼までの鉄鋼生産管理に 広く使用するため汇必要な諸検討を加之た結果, 鉄鋼試 料に対しては彷来の化学分析法に比較してそえ色のない 精度でしかも各種マトリックス効果を一応度外視てきる 発光方式およびそれぞれの発光条件を選定できだ.また スラグのような酸化物質も任意の標準試料を作成できる ブリケット法の適用によつて広裖度範囲にわたつて迅速 分析が可能になつた。
なお本装置を連日各種の試料に対して適用してゆくに は精度維持および器械保守のために簡便かつ適切な管理 方式をとる必要を痛感したが，信頼性のある標準試料に よる記録值の補正と内標準元素濃度による試料および発 光条件の監視によつて一応その方式を確立することがで きた.

最後に本研究を行うに当つて格別の御便宜を賜つた 鈴木甫常務取締役に哚甚なる謝意を表する.

\section{交献}

1) H. Steinberg \& H. Belic: Anal. Chem., 20 (1948), p. 72

2) 中島, 河口, 高島, 宇留島: 分析化学, 10 (1961), p. 221

3 ) N. H. Nachtrieb: "Principles and Practices of Spectrochemical Analysis”, p. 215

4) 吉野, 酒井, 金子: 分光研究, 10 (1961), p. 45

5 ) 鹿島, 安田: 分析化学, 7 (1958), p. 459

6 ) 大藤：日本金属学会誌, 20 (1956), p. 683

7 ) R. Bartel \& Goldblatt: Spectrochim. Acta, 9 (1957), p. 227

8 ) 島津, 佐野, 松井: 分光研究, 7 (1958), No. 2 p. 26

9) H E. Biber \& S. Leuy: J. Opt. Soc. Am., 49 (1959), p. 349

10）浜口, 仲尾：分光研究, 6 (1957), No.2, p. 13

11）大藤, 浜口, 松本, 吉仲, 仲尾: 日本金属学会誌 19 (1955), p. 700

12) 細田, 小野, 酒井, 沢田：分析化学討論会（1962 年 5 月）にて発表

13) M. Milbourn \& H.E.R. Harttey: Spectrochim. Acta, 3 (1 48 ), p. 320

14) J. T. RozsA: "Methods for Emission Spectrochemical Analysis", (1955), p. 283

15) H. C. Harrison \& C. C. Ralph: Ind. Eng. Chem., Anal. Ed., 15 (1943), p. 466 